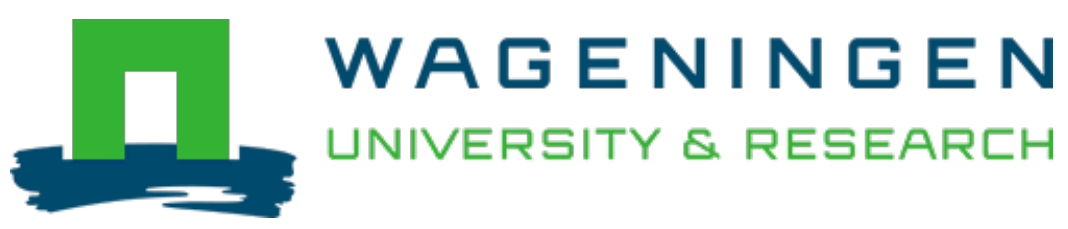

\title{
Yeasts and lactic acid bacteria microbiota from masau (Ziziphus mauritiana) fruits and their fermented fruit pulp in Zimbabwe
}

\author{
International Journal of Food Microbiology \\ Nyanga, L.K.; Nout, M.J.R.; Gadaga, T.H.; Theelen, R.M.C.; Boekhout, T. et al \\ https://doi.org/10.1016/j.ijfoodmicro.2007.06.021
}

This publication is made publicly available in the institutional repository of Wageningen University and Research, under the terms of article $25 \mathrm{fa}$ of the Dutch Copyright Act, also known as the Amendment Taverne. This has been done with explicit consent by the author.

Article 25 fa states that the author of a short scientific work funded either wholly or partially by Dutch public funds is entitled to make that work publicly available for no consideration following a reasonable period of time after the work was first published, provided that clear reference is made to the source of the first publication of the work.

This publication is distributed under The Association of Universities in the Netherlands (VSNU) 'Article $25 \mathrm{fa}$ implementation' project. In this project research outputs of researchers employed by Dutch Universities that comply with the legal requirements of Article $25 \mathrm{fa}$ of the Dutch Copyright Act are distributed online and free of cost or other barriers in institutional repositories. Research outputs are distributed six months after their first online publication in the original published version and with proper attribution to the source of the original publication.

You are permitted to download and use the publication for personal purposes. All rights remain with the author(s) and / or copyright owner(s) of this work. Any use of the publication or parts of it other than authorised under article $25 \mathrm{fa}$ of the Dutch Copyright act is prohibited. Wageningen University \& Research and the author(s) of this publication shall not be held responsible or liable for any damages resulting from your (re)use of this publication.

For questions regarding the public availability of this publication please contact openscience.library@wur.nl 


\title{
Yeasts and lactic acid bacteria microbiota from masau (Ziziphus mauritiana) fruits and their fermented fruit pulp in Zimbabwe
}

\author{
Loveness K. Nyanga $^{\mathrm{a}, \mathrm{b}}$, Martinus J.R. Nout ${ }^{\mathrm{b}, *}$, Tendekayi H. Gadaga ${ }^{\mathrm{a}}$, Bart Theelen ${ }^{\mathrm{c}}$, \\ Teun Boekhout ${ }^{\mathrm{c}}$, Marcel H. Zwietering ${ }^{\mathrm{b}}$ \\ ${ }^{a}$ Institute of Food, Nutrition and Family Sciences, University of Zimbabwe, P. Box MP167, Mt Pleasant, Harare, Zimbabwe \\ ${ }^{\mathrm{b}}$ Laboratory of Food Microbiology, Department of Agrotechnology and Food Sciences, \\ Wageningen University, P.O. Box 8129, 6700EV Wageningen, The Netherlands \\ ${ }^{\mathrm{c}}$ Centraalbureau voor Schimmelcultures, P. O. Box 85167, 3508 AD Utrecht, The Netherlands
}

\begin{abstract}
Masau are Zimbabwean wild fruits, which are usually eaten raw and/ or processed into products such as porridge, traditional cakes, mahewu and jam. Yeasts, yeast-like fungi, and lactic acid bacteria present on the unripe, ripe and dried fruits, and in the fermented masau fruits collected from Muzarabani district in Zimbabwe were isolated and identified using physiological and molecular methods. The predominant species were identified as Saccharomyces cerevisiae, Issatchenkia orientalis, Pichia fabianii and Aureobasidium pullulans. A. pullulans was the dominant species on the unripe fruits but was not isolated from the fermented fruit pulp. S. cerevisiae and I. orientalis were predominant in the fermented fruit pulp but were not detected in the unripe fruits. S. cerevisiae, I. orientalis, P. fabianii and S. fibuligera are fermentative yeasts and these might be used in the future development of starter cultures to produce better quality fermented products from masau fruit. Lactic acid bacteria were preliminary identified and the predominant strains found were Lactobacillus agilis and L. plantarum. Other species identified included L. bifermentans, L. minor, L. divergens, L. confusus, L. hilgardii, L. fructosus, L. fermentum and Streptococcus spp. Some of the strains of LAB could also potentially be used in a mixed-starter culture with yeasts and might contribute positively in the production of fermented masau fruit products.
\end{abstract}

(C) 2007 Elsevier B.V. All rights reserved.

Keywords: Masau fruits; Yeasts; Lactic acid bacteria; Starter cultures; Fermentation

\section{Introduction}

Ziziphus mauritiana fruit, which is locally called masau fruit in Zimbabwe, is one of the wild fruits that are traditionally fermented into beverages through spontaneous and uncontrolled processes. Other wild fruits that are spontaneously fermented include mapfura (Sclerocarya birrea subspecies caffra), hacha (Parinari curatellifolia) and mazhanje (Uapaca kirkiana) (Gadaga et al., 1999). However, because the fermentations are spontaneous and uncontrolled, the product microbiota are inconsistent and the fermented products are of variable quality (Halm et al., 1993; Sanni et al., 1994; Gadaga, 2000). Their fermentation mainly relies on the microbiota from

\footnotetext{
* Corresponding author. Tel.: +3131748 28 87; fax: +31 317484978 .
} E-mail address: rob.nout@wur.nl (M.J.R. Nout). the fruit surfaces and to some extent from the utensils used during the fermentation process. The diverse microbial flora on fruit surfaces may play an important role during the spontaneous fermentation process (Fleet, 2003). The type of microorganisms includes coliforms, lactic acid bacteria, yeasts and moulds (Mbugua, 1985). The spontaneous fermentation of grape juice into wine, as observed by Louis Pasteur about 150 years ago, established the broadly accepted view that yeasts have a natural association with fruits and fruit products (Fleet, 2003). Z. mauritiana was also reported previously to be among the Zimbabwean indigenous fruits that are associated with high numbers of microbes which contribute to the natural fermentation following ripening (Chivero et al., 2001).

In Zimbabwe, masau fruits are spontaneously fermented for 67 days and then distilled into a potent spirit called kachasu (Tredgold, 1986; Gadaga et al., 1999), that is highly intoxicating and is 
regarded as illegal beverage (Brett et al., 1992). The fermented fruit pulp is not consumed as such, because of its unattractive exterior and smell. Kachasu is consumed as a beverage by the local people and its alcohol content varies from producer to producer.

The microbial changes taking place during the spontaneous fermentation of masau have not been recorded. The objective of this study, therefore is to isolate and identify yeasts and LAB microbiota that are involved in the spontaneous fermentation of masau fruit pulp and on the whole fruit. This will be followed in future by the selection and development of starter cultures to produce better quality fermented products from masau fruits.

\section{Materials and methods}

\subsection{Sample collection}

The collection and analysis of samples was done during two consecutive years 2004 and 2005 in the month of August when masau fruits are in season. Both ripe and unripe masau fruits were harvested from Muzarabani $\left(16^{\circ} 20^{\prime} \mathrm{S}, 31^{\circ} 21^{\prime} \mathrm{E}\right)$ district in Northern Zimbabwe. Dried fruit samples were obtained from the local people who ferment the fruits. The fruits were collected into sterile stomacher bags (Stomacher ${ }^{\circledR}$ Lab System, London, UK) and ferried to the laboratory in a cooler box. Fermented samples $(200 \mathrm{ml})(n=7$ for each year) were collected into sterile $250 \mathrm{ml}$ screw capped bottles (Schott Duran, Elmsford, NY) from the local people in Muzarabani. Samples of distilled product made from masau fruits were also collected into $250 \mathrm{ml}$ sterile bottles. These samples were also transported to the laboratory in a cooler box and were kept at $5{ }^{\circ} \mathrm{C}$ on arrival and processed the following day.

\subsection{Microbiological analyses}

\subsubsection{Isolation of yeasts and $L A B$ from masau fruits and the fermented fruit pulp}

Masau fruits $(100 \mathrm{~g})$ were aseptically weighed and transferred into sterile $250 \mathrm{ml}$ bottles containing Peptone Physiological Saline $(100 \mathrm{ml})[0.8 \% \mathrm{NaCl}$ (Merck, Darmstadt, Germany), $0.1 \%$ neutral peptone (Oxoid, Basingstoke, UK); PPS]. The bottles were vigorously shaken by hand for $10 \mathrm{~min}$. Appropriate serial dilutions were plated in duplicate on Malt Extract Agar (MEA) (Oxoid) containing 0.1\% oxytetracycline (Sigma-Aldrich Co., St Louis, MO, USA), and on de Man, Rogosa, Sharpe (MRS) agar (Oxoid) containing $0.1 \%$ natamycin (Aldrich Chemical Co., Gillingham, Dorset, England). Similarly, appropriate serial dilutions were also made from the fermented fruit pulp samples and plated in duplicate on MEA containing $0.1 \%$ oxytetracycline and MRS agar containing $0.1 \%$ natamycin. The MEA plates were incubated at $25{ }^{\circ} \mathrm{C}$ for $48 \mathrm{~h}$. MRS agar plates were incubated at $37{ }^{\circ} \mathrm{C}$ for $48 \mathrm{~h}$ under anaerobic conditions using the $\mathrm{BBL}^{\circledR}$ Gas $\mathrm{Pak}^{\circledR}$ Anaerobic Systems (Becton Dickinson Company, Maryland, USA) according to the manufacturer's instructions. After the incubation a differential count based on colony colour was made for yeasts of different colony morphology, whereas presumptive LAB colonies were counted on the MRS agar plates.

\subsubsection{Purification of yeasts and $L A B$}

Morphologically distinct yeast and LAB colonies were selected and purified by making streak plates on MEA and MRS respectively. The MEA plates were incubated at $25^{\circ} \mathrm{C}$ for $48 \mathrm{~h}$ and the MRS plates were incubated as mentioned above.

\subsubsection{Morphological characterization of yeasts}

Yeast strains were streaked on Glucose Peptone Yeast Extract Agar [2\% D-glucose (Merck), $0.5 \%$ bacto peptone (Oxoid), 0.5\% yeast extract (Oxoid), and 2\% agar (Oxoid); GPYA] plates and incubated at $25{ }^{\circ} \mathrm{C}$ for 7 days and examined for characteristics such as colony appearance, cell shape and presence of filaments (Kurtzman et al., 2003).

\subsection{Phenotypical characterization of yeasts}

The phenotypic characteristics of the yeast isolates were examined using conventional tests as described by Kurtzman et al. (2003). These included ability to ferment sugars, assimilation of nitrogen compounds, diazonium blue B test, production of acetic acid and growth at different temperatures. The ability of yeasts to ferment sugars was detected by examining the cultures for production of $\mathrm{CO}_{2}$ gas. A filter sterilized solution of $6 \%$ of any of the sugars [2 $\mathrm{ml}$; glucose, galactose, sucrose, maltose, lactose and raffinose (Sigma Chemical Co., St Louis, MO, USA)] was gently mixed with sterile $2 \%(\mathrm{w} / \mathrm{v})$ yeast extract broth $(4 \mathrm{ml})$ in a test tube containing an inverted Durham tube. A yeast cell suspension $(0.2 \mathrm{ml})$ was then added and the tube was incubated at $25^{\circ} \mathrm{C}$. Observations were made after every two days for 28 days. Assimilation of nitrate (Merck), nitrite (Merck), ethylamine (Acros Organics, New Jersey, USA), L-lysine (Acros), cadaverine (Acros), creatine (Merck), imidazole (Merck) and ammonium sulphate (Merck) by the yeast strains was tested using the auxanogram method. To test for the production of acetic acid, a small amount of yeast inoculum was streaked onto plates of GPYA with $0.5 \% \mathrm{w} / \mathrm{v} \mathrm{CaCO}_{3}$ (Merck). The production of acetic acid was observed as a clear zone around the culture. The growth of yeasts at different temperatures was tested by streaking the culture on a slant of GPYA and incubating for 5 days at the following temperatures: $25^{\circ} \mathrm{C}, 30^{\circ} \mathrm{C}, 37^{\circ} \mathrm{C}, 42^{\circ} \mathrm{C}$ and $45{ }^{\circ} \mathrm{C}$. In addition, the ability of the yeast isolates to assimilate carbon compounds was tested using the API 20C kit (Bio-Mérieux, Marcy l'Etoile, France) according to the manufacturer's instructions.

\subsection{Genotypical identification of yeasts}

\subsubsection{DNA extraction}

DNA was extracted according to the cetyltrimethylammonium bromide $(\mathrm{CTAB})$ method. Yeast cells $(500 \mu \mathrm{l})$ were transferred to a $1.5 \mathrm{ml}$ Eppendorf tube, before adding $\mathrm{CTAB}$ buffer $(800 \mu \mathrm{l})$ (O'Donnel et al., 1997). The suspension was mixed using a vortex mixer and incubated for $1 \mathrm{~h}$ at $65^{\circ} \mathrm{C}$, with vigorous shaking at $15 \mathrm{~min}$ intervals. The suspension was centrifuged at 21,000 $\mathrm{g}$ in an Eppendorf bench top centrifuge for $30 \mathrm{~min}$ at $4{ }^{\circ} \mathrm{C}$. The supernatant $(700 \mu \mathrm{l})$ was transferred to a 
fresh $1.5 \mathrm{ml}$ Eppendorf tube. Subsequently, chloroformisoamylalcohol ( $700 \mu \mathrm{l}, 24: 1$ by volume) was added, and the solution was shaken vigorously. The solution was then centrifuged at $21,000 \mathrm{~g}$ for $20 \mathrm{~min}$ at $4{ }^{\circ} \mathrm{C}$ and the supernatant $(500 \mu \mathrm{l})$ was transferred to a fresh Eppendorf tube. To this solution, chloroform-isoamylalcohol $(500 \mu \mathrm{l})$ was added, and the suspension was centrifuged again at 21,000 $\mathrm{g}$ for $10 \mathrm{~min}$ at $4{ }^{\circ} \mathrm{C}$. From this suspension, a portion of the aqueous layer $(350 \mu 1)$ was pipetted and mixed with CTAB buffer $(150 \mu 1)$. To this, ice-cold isopropanol $\left(300 \mu \mathrm{l}\right.$, kept at $\left.-20{ }^{\circ} \mathrm{C}\right)$ was added, and the DNA was precipitated by centrifugation at $21,000 \mathrm{~g}$ for $10 \mathrm{~min}$ at $4{ }^{\circ} \mathrm{C}$. The pellet obtained was washed with $70 \%$ alcohol. It was dried and then suspended in sterile water $(100 \mu \mathrm{l})$ containing RNase $(4 \mu \mathrm{l} ; 10 \mathrm{mg} / \mathrm{ml})$ (USB Corp., Cleveland, Ohio). The samples were stored at $-20{ }^{\circ} \mathrm{C}$.

\subsubsection{PCR amplification and sequencing of Internal} Transcribed Spacer (ITS) and Large Subunit (LSU) regions

The sequencing of the ITS $1+2$ regions of the rDNA and the D1/D2 domains of the 26s rRNA was done using the procedures described by Gupta et al. (2004). The nucleotide sequences obtained were identified using BLAST.

\subsubsection{Amplified Fragment Length Polymorphism (AFLP) analysis}

AFLP analysis (Vos et al., 1995) was performed according to the manufacturer's instructions in the AFLP microbial fingerprinting protocol (Applied Biosystems), with some modifications according to the method described by Gupta et al. (2004) for the construction of the dendrogram.

\subsection{Physiological identification of $L A B$}

The 35 isolates of LAB were confirmed using the regular Gram stain method, the catalase and oxidase tests, and characterized by their growth at different temperatures and assimilation of carbon compounds. The presence of catalase activity was observed by formation of gas bubbles after suspension of bacterial cells in a droplet of 3\% hydrogen peroxide. The oxidase reaction of $\mathrm{LAB}$ was determined using BBL DrySlide Oxidase (Difco) according to the manufacturer's instructions. The growth of LAB was tested by inoculating the culture into MRS broth and incubating for 5 days at $15^{\circ} \mathrm{C}$ and $45{ }^{\circ} \mathrm{C}$. The carbohydrate fermentation profiles of the $\mathrm{LAB}$ isolates were investigated using API $50 \mathrm{CHL}$ strips and API CHL medium according to the manufacturer's instructions (Bio-Merieux). Using the data obtained from the above mentioned tests the LAB were then identified using Intelligent Bacteria Identification System (IBIS) software (Wijtzes et al., 1997).

\section{Results and discussion}

\subsection{Enumeration of yeasts}

Yeast strains (107 isolates) were isolated from the unripe, ripe and dried fruits, and the fermented fruit pulp. The yeasts
Table 1

Yeast counts from masau (Z. mauritiana) fruits and fermented masau fruit pulp from Muzarabani district in Zimbabwe

\begin{tabular}{lll}
\hline Fruit sample & \multicolumn{2}{l}{ Yeasts $\left(\log \mathrm{CFU} \mathrm{g}^{-1}\right)$} \\
\cline { 2 - 3 } & Red/pink & Cream/white \\
\hline Unripe $(n=10)$ & $3.74 \pm 0.09^{\mathrm{a}}$ & $3.30 \pm 0.1$ \\
Ripe $(n=10)$ & $2.97 \pm 0.03$ & $3.93 \pm 0.04$ \\
Dried $(n=10)$ & $1.23 \pm 0.04$ & $4.28 \pm 0.02$ \\
Fermented $(n=14)$ & $<4$ & $9.26 \pm 0.4$ \\
\hline
\end{tabular}

${ }^{\text {a }}$ Values are means \pm standard deviation of $\mathrm{n}$ determinants (two harvests); each determinant was calculated as the average of a duplicate.

had different morphological characteristics and could be grouped according to the colour of their colonies, namely red/ pink and cream/white as shown in Table 1 . Generally there was a decrease in the red/pink yeast population and an increase in the cream/white yeast population from the unripe fruit to the fermented fruit pulp. The yeast populations obtained in the ripe fruits are comparable to the literature values (ranging from 2 to

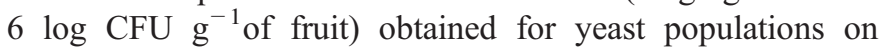
different types of ripe fruit surfaces such as apples, grapes and strawberries (Rosini et al., 1982; Dennis and Davis, 1977; Beech, 1993). Fleet (2003) also reported that the yeasts responsible for the fermentation originate from the surface of the fruit, contact with processing equipment and other environmental sources, and developed into communities as dense as $7-8 \log \mathrm{CFU} \mathrm{g}^{-1}$, which is similar to yeast population counts (approximately $9.26 \log \mathrm{CFU} \mathrm{g}{ }^{-1}$ ) obtained in the fermented fruit pulp in this study.

\subsection{Identification of yeasts}

Morphologically distinct colonies of yeasts were picked and identified (Tables 2 and 3) using the methods as described by Deak (1993, 2003), Kurtzman et al. (2003) and Gupta et al. (2004). From the yeast strains isolated, 14 different species were identified namely: Saccharomyces cerevisiae (21 strains), Issatchenkia orientalis (25 strains), Pichia fabianii (12 strains), Aureobasidium pullulans (26 strains), Candida glabrata (3 strains), Pichia ciferrii (3 strains), Saccharomycopisis fibuligera (2 strains), Hanseniaspora opuntiae (1 strain), Zygoascus hellenicus (2 strains), Cryptococcus flavus (1 strain), Cryptococcus magnus (1 strain), Candida parapsilosis (1 strain), Candida pyralidae (1 strain) and Rhodotorula mucilaginosa (1 strain) (Table 4). Seven of the isolates could not be identified. However, according to the data obtained by sequencing the ITS and LSU regions the closest identification for the isolates 002, 008, 98, 97, 112, 92 and 95 were Cryptococcus heveanensis, Bullera dendrophila, Fusarium lichenicola (mould), Filobasidium floriforme, Cryptococcus chernovii, C. flavus and Myrothecium roridum respectively. The red/pink yeasts enumerated in Table 1 represent $A$. pullulans, C. flavus and R. mucilaginosa which were found dominantly on the unripe fruits; these are all non-fermentative yeasts. The cream/white group that was predominant includes all the other identified yeast species and comprised both 
Table 2

Identification of yeasts isolated from masau fruits and fermented masau fruit pulp from Muzarabani district in Zimbabwe

\begin{tabular}{|c|c|c|c|c|c|c|c|}
\hline \multirow[t]{2}{*}{ Substrate } & \multicolumn{7}{|c|}{ Identity and strain reference number } \\
\hline & $\begin{array}{l}\text { Saccharomyces } \\
\text { cerevisiae }(135,124, \\
141,38,146,131, \\
126,168,165,143, \\
142,149,102,153, \\
128,148,46,139, \\
160,116,130)\end{array}$ & 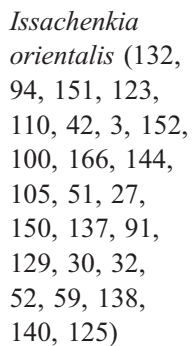 & $\begin{array}{l}\text { Pichia fabianii } \\
(145,167, \\
70,76,1 \mathrm{a}, \\
2 \mathrm{a}, 4 \mathrm{a}, 6 \mathrm{a} 1, \\
65,6 \mathrm{a} 2, \\
8 \mathrm{a} 1,8 \mathrm{a} 2)\end{array}$ & $\begin{array}{l}\text { Saccharomycopsis } \\
\text { fibuligera } \\
(3 \mathrm{a}, 66)\end{array}$ & $\begin{array}{l}\text { Hanseniaspora } \\
\text { opuntiae } \\
(54)\end{array}$ & $\begin{array}{l}\text { Aureobasidium } \\
\text { pullulans }(3,5, \\
6,7,9,13,10, \\
72,16,19,20, \\
37,73,63,75, \\
119,109,99, \\
104,56,61, \\
74,57,58, \\
64)\end{array}$ & $\begin{array}{l}\text { Candida } \\
\text { glabrata } \\
(133,134, \\
147)\end{array}$ \\
\hline
\end{tabular}

\section{Fermentation of:}

Glucose
Maltose
Galactose
Raffinose

Assimilation of:

$(115,164,169)$

$\begin{array}{ll}\text { Glucose } & + \\ \text { Galactose } & \mathrm{V} \\ \text { MDG } & \mathrm{V} \\ \text { Cellobiose } & - \\ \text { Lactose } & - \\ \text { Maltose } & + \\ \text { Saccharose } & + \\ \text { Trehalose } & \mathrm{V} \\ \text { Melezitose } & \mathrm{V} \\ \text { Raffinose } & \mathrm{V} \\ \text { L-lysine } & - \\ \text { Cadaverine } & - \\ \text { Creatine } & \mathrm{V} \\ \text { Growth at } 37^{\circ} \mathrm{C} & + \\ & \end{array}$

$\mathrm{V}$
-
nd
-
-

$\begin{array}{ll}+ & + \\ + & + \\ \mathrm{V} & + \\ - & \mathrm{nd} \\ - & \mathrm{nd}\end{array}$

$\begin{array}{ll}+ & \\ + & + \\ + & + \\ \text { nd } & + \\ \text { nd } & -\end{array}$

$\begin{array}{ll}+ & - \\ + & - \\ + & - \\ + & - \\ - & -\end{array}$

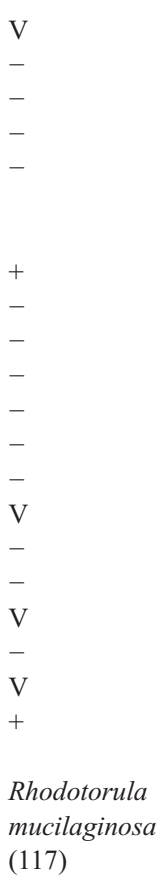

Fermentation of:

$\begin{array}{ll}\text { Glucose } & + \\ \text { Sucrose } & + \\ \text { Maltose } & \text { nd } \\ \text { Galactose } & - \\ \text { Raffinose } & -\end{array}$

$\begin{array}{ll}\text { Cryptococcus } & \text { Cryptoccus } \\ \text { flavus (11) } & \text { magnus }(71)\end{array}$

Zygoascus hellenicus $(121,122)$

+
+
-
-
+
+
+
+
+
+
nd
nd
nd
+

\section{Candida parapsilosis (93)}

$\begin{array}{cc}+ & + \\ \mathrm{V} & - \\ \mathrm{V} & - \\ + & - \\ \mathrm{V} & - \\ + & - \\ + & - \\ + & \mathrm{V} \\ + & - \\ + & - \\ + & \mathrm{V} \\ + & - \\ + & \mathrm{V} \\ + & +\end{array}$

$\begin{array}{ll}\text { Candida } & \text { Rhodotorula } \\ \text { pyralidae } & \text { mucilaginosa } \\ (90) & (117)\end{array}$

$\begin{array}{ll}+ & - \\ + & - \\ \text { nd } & \text { nd } \\ - & \text { nd } \\ - & \text { nd }\end{array}$

$\begin{array}{ll}- & + \\ - & + \\ - & \text { nd } \\ - & + \\ - & \text { nd }\end{array}$

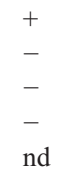

$\begin{array}{ll}- & - \\ - & - \\ \text { nd } & - \\ - & - \\ \text { nd } & -\end{array}$

Assimilation of:

Glucose

Galactose

MDG

Cellobiose

Lactose

Maltose

Saccharose

Trehalose

Melezitose

Raffinose

L-lysine

Cadaverine

Creatine

Growth at

$37{ }^{\circ} \mathrm{C}$

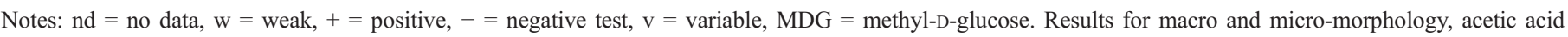

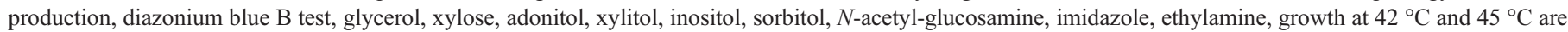
not included in the table. 
Table 3

The diversity of yeasts isolated from masau (Z. mauritiana) fruits and fermented masau fruit pulp from Muzarabani rural community in Zimbabwe

\begin{tabular}{lllll}
\hline Yeast species & \multicolumn{4}{l}{ No of isolates detected in fruits } \\
\cline { 2 - 5 } & Unripe & Ripe & Dried & Fermented \\
\hline Fermentative: & & $1^{\text {a }}$ & - & 20 \\
S. cerevisiae & - & 3 & - & 22 \\
I. orientalis & - & - & 8 & 4 \\
P. fabianii & - & - & 1 & 1 \\
S. fibuligera & - & - & - & 1 \\
H. opuntiae & - & & & \\
Non-fermentative: & & & & \\
A. pullulans & 19 & 1 & 6 & - \\
C. glabrata & - & - & - & 3 \\
P. ciferrii & - & - & 3 & - \\
Cr. magnus & - & 1 & - & - \\
Cr. flavus & 1 & - & - & - \\
Z. hellenicus & - & 2 & - & - \\
C. parapsilosis & - & 1 & - & - \\
C. pyralidae & - & 1 & - & - \\
R. mucilaginosa & 1 & - & - & - \\
\hline- = not found. & & & & \\
a Values are combined data from the two harvests.
\end{tabular}

fermentative and non-fermentative yeasts. These results represent yeast isolates selected from the two harvests and it was observed that $H$. opuntiae, Cr. magnus, and yeasts 002 and 008 were only encountered in the samples collected in 2004. C. glabrata, P. ciferrii, Cr. flavus, C. parapsilosis, $C$. pyralidae, R. mucilaginosa, Z. hellenicus, and the yeasts 92 , 95, 97, 98 and 112 were found only in the samples collected in 2005. The reason why certain yeast species were not found in year one and others in year two could be that they were missed during the selection since they occurred less frequently when compared to the other yeast species found in both harvests. All the other species were common in both years. However, the comparison could not be done in terms of CFU's because in 2004 less of the cream colonies were picked for identification since they appeared the same on solid media, and in 2005 more cream colonies were picked for identification.

The fruit surface presents an environment of limited nutrient availability, depending on the concentration of sugars, organic acids and amino acids, which leach from the underlying tissue. Many factors affect the populations and community structure of yeasts that are present on any one type of fruit, including fruit cultivars, geographic location, and fruit developmental stage (Fleet, 2003). In this study the unripe fruit surface was colonised mainly by A. pullulans. Clark et al. (1954) and also Chand-Goyal and Spotts (1996), reported A. pullulans's relative abundance as highest among the yeast/yeast like fungi colonising the surface of pears and apples. This fungus also causes russeting of apples (Okagbue and Siwela, 2002; Gildemacher et al., 2006). A. pullulans has also been isolated from tropical plant leaves, marula fruits, flowers, pulp and juices in Zimbabwe (Okagbue et al., 2001). It is an important microorganism in applied microbiology and biotechnology because of the extracellular enzymes it produces, that have industrial applications (Deshpande et al., 1992; Okagbue et al., 2001). Other yeast species which were identified on the unripe fruits included Cr. flavus and R. mucilaginosa. The ripe fruits were colonised by a wide range of yeasts species (Table 3) comprising fermentative as well as non-fermentative yeasts. On the ripe masau fruits, S. cerevisiae was found less frequently than in the fermented fruit pulp. The gradual transition from non-fermentative species in unripe fruits, through mixed populations in ripe fruit, towards predominantly fermentative species in fermented pulp is evident, and we assume that this is strongly related with the evolving degree of maturity and ensuing chemical composition and softening of consistency. This phenomenon is similar as in grape fermentation for wine production (Rosini et al., 1982; Heard and Fleet,

\section{Table 4}

Identification of yeasts isolated from masau (Z. mauritiana) fruits and fermented masau fruit pulp by D1/D2 domains of 26s rRNA (LSU) and ITS sequence analysis

\begin{tabular}{|c|c|c|c|c|c|}
\hline $\begin{array}{l}\text { Species and } \\
\text { group no. }\end{array}$ & $\begin{array}{l}\text { No of } \\
\text { strains }\end{array}$ & $\begin{array}{l}\text { ITS } \\
\text { accession } \\
\text { no. }\end{array}$ & $\begin{array}{l}\text { LSU } \\
\text { accession } \\
\text { no. }\end{array}$ & $\begin{array}{l}\% \text { similarity } \\
\text { of ITS } \\
\text { sequences }\end{array}$ & $\begin{array}{l}\% \text { similarity } \\
\text { of LSU } \\
\text { sequences }\end{array}$ \\
\hline \multicolumn{6}{|l|}{ S. cerevisiae } \\
\hline Group $1^{\mathrm{a}}$ & 5 & AB212260.1 & AJ746340.1 & 99 & 100 \\
\hline Group 2 & 7 & AB212260.1 & AJ746340.1 & 99 & 99 \\
\hline Group 3 & 3 & AB212260.1 & AJ746340.1 & 99 & 100 \\
\hline Group 4 & 3 & AB212260.1 & AY601161.1 & 99 & 99 \\
\hline Group 5 & 2 & DQ167471.1 & AJ746340.1 & 99 & 99 \\
\hline Group 6 & 1 & AB212260.1 & Z7332.1 & 99 & 99 \\
\hline \multicolumn{6}{|l|}{ I. orientalis } \\
\hline Group 1 & 9 & AY939808.1 & AY707865.1 & 100 & 100 \\
\hline Group 2 & 5 & AY939808.1 & AY601160.1 & 99 & 99 \\
\hline Group 3 & 3 & AY939808.1 & AY707865.1 & 100 & 99 \\
\hline Group 4 & 5 & AY939808.1 & AY707865.1 & 99 & 100 \\
\hline Group 5 & 3 & AY939808.1 & AY707865.1 & 99 & 99 \\
\hline \multicolumn{6}{|l|}{ P. fabianii } \\
\hline Group 1 & 1 & AF335967.1 & AF335967.1 & 100 & 100 \\
\hline Group 2 & 1 & AF335967.1 & AF335967.1 & 99 & 99 \\
\hline Group 3 & 2 & AF335967.1 & AF335967.1 & 100 & 99 \\
\hline Group 4 & 7 & AF335967.1 & AF335967.1 & 99 & 100 \\
\hline Group 5 & 1 & AF335967.1 & AF335967.1 & 99 & 99 \\
\hline \multicolumn{6}{|l|}{ S. fibuligera } \\
\hline Group 1 & 1 & AF335940.1 & U40088.1 & 99 & 100 \\
\hline Group 2 & 1 & U410409.1 & U40088.1 & 99 & 99 \\
\hline \multicolumn{6}{|l|}{ A. pullulans } \\
\hline Group 1 & 13 & AY225166.1 & AF050239.1 & 99 & 100 \\
\hline Group 2 & 4 & AY225166.1 & AF050239.1 & 99 & 100 \\
\hline Group 3 & 3 & AY225166.1 & AF050239.1 & 99 & 100 \\
\hline Group 4 & 4 & AY139394.1 & AF050239.1 & 99 & 100 \\
\hline Group 5 & 1 & Ay225166.1 & AF050239.1 & 99 & 100 \\
\hline Group 6 & 1 & AY625057.1 & AY18811.1 & 99 & 96 \\
\hline \multicolumn{6}{|l|}{ C. glabrata } \\
\hline Group 1 & 2 & AY939749.1 & AY198398.1 & 99 & 99 \\
\hline Group 2 & 1 & nd & AJ617300.1 & nd & 100 \\
\hline P. ciferrii & 3 & nd & U74587.1 & nd & 100 \\
\hline Cr. flavus & 1 & AF444338.1 & AF075497 & nd & 99 \\
\hline Cr. magnus & 1 & AF444450.1 & AY362182.1 & 99 & 100 \\
\hline Z. hellenicus & 2 & AY447022.1 & AY 447006.1 & 99 & 100 \\
\hline C. parapsilosis & 1 & AJ49821.1 & AY391843.1 & 99 & 99 \\
\hline C. pyralidae & 1 & AY013715 & AY498864.1 & 98 & 99 \\
\hline H. opuntiae & 1 & nd & AY267820.1 & nd & 100 \\
\hline R. mucilaginosa & 1 & DQ386306.1 & AB02610.2 & 98 & 99 \\
\hline
\end{tabular}

nd = no data.

a The groups are based on the sequencing consensus similarity. 
1985; Fleet, 2003). Difficulties to detect or isolate $S$. cerevisiae from either immature or mature grapes, have been reported elsewhere (Martini et al., 1996; Van der Westhuizen et al., 2000). P. fabianii was recorded highest on the dried fruits probably because it is able to thrive under reduced water activity. The fermented fruit pulp harboured a predominance of $S$. cerevisiae, I. orientalis and P. fabianii and other minor species like $S$. fibuligera, C. glabrata and H. opuntiae. These

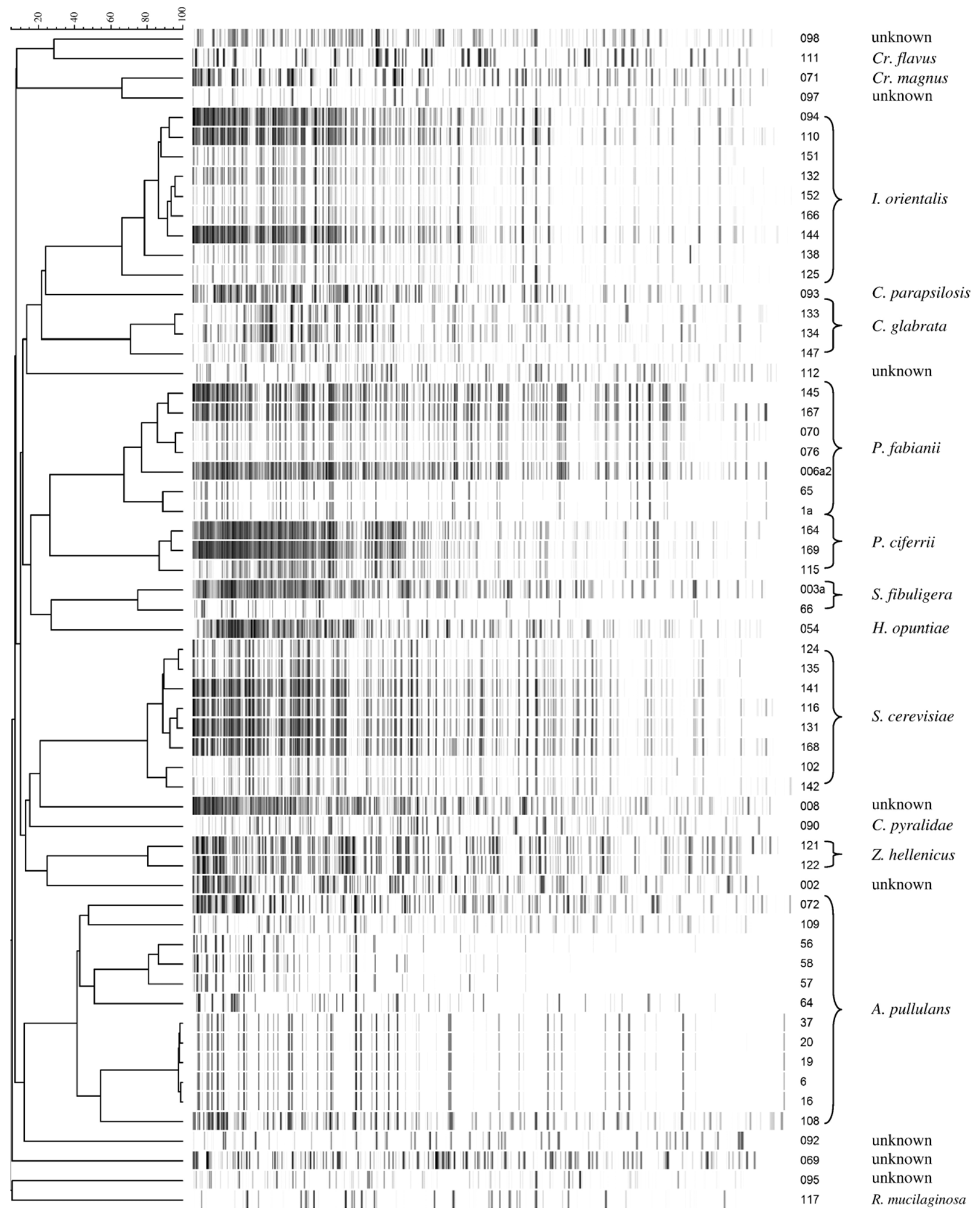

Fig. 1. AFLP dendrogram representing the identified and unidentified yeast species isolated from masau (Z. mauritiana) fruits and fermented fruit pulp. 
are all fermentative yeasts, which have also been reported as predominating in traditional fermented foods such as Korean nuruk, Nigerian fufu and Indian idli (Nout, 2003).

The yeast species were grouped based on their physiological properties and molecular data obtained from sequencing of D1/ D2 domains and ITS $1+2$ regions as well as AFLP fingerprinting. The sequencing results in Table 4 show the accession number and percentage similarity for both the LSU and ITS of the different yeast species. The molecular identification techniques were used in combination with conventional methods of identification in order to confirm the identities and to assess relatedness among the yeast species. A dendrogram based on the AFLP analysis representing all yeasts species isolated is depicted in Fig. 1. The AFLP patterns clearly show that each species forms a distinct cluster. Common bands as well as different bands were observed thus showing the DNA polymorphisms among the isolates of the same yeasts species. This is particularly clear for isolates belonging to A. pullulans.

The biodiversity seen in our isolates of $S$. cerevisiae has also been observed in other studies on African indigenous fermented foods and beverages (Jespersen, 2003). Not all the strains had assimilation profiles typical for $S$. cerevisiae and this could probably be explained by the polymorphisms seen in Fig 1 . Some of the strains were shown to be weak in fermenting both sucrose and galactose. Variability was also shown in acetic acid production, assimilation of carbon compounds (galactose, inositol, methyl $\alpha$-D-glucoside, $N$-acetyl-glucosamine, saccharose, melezitose and raffinose) and growth at $42{ }^{\circ} \mathrm{C}$ and $45^{\circ} \mathrm{C}$. In total, six assimilation profiles were distinguished.

\subsection{Lactic acid bacteria}

Yeasts are not the only organisms of importance in the microbiology of fruit and fruit products. Bacteria, especially lactic acid bacteria (LAB) and acetic acid bacteria, are prominent in the spoilage of some fruits and fruit products, and certain species of $\mathrm{LAB}$ can have positive contribution in the production of wines (Fleet, 2003). In most indigenous fermentation processes, yeasts occur in association with $\mathrm{LAB}$ (Sanni, 1993; Gobbetti et al., 1994; Caplice and Fitzgerald, 1999; Fleet, 1999; Jespersen, 2003; Nout, 2003). This was also observed in this study whereby LAB and yeasts were found coexisting in masau fruits and the fermented fruit pulp.

Table 5

Lactic acid bacteria from masau (Z. mauritiana) fruits and fermented masau fruit pulp

\begin{tabular}{ll}
\hline Fruit & Lactic acid bacteria ${ }^{\mathrm{a}}\left(\log C F U \mathrm{~g}^{-1}\right)$ \\
\hline Unripe $(n=10)$ & $<2$ \\
Ripe fruits $(n=10)$ & $2.99 \pm 0.07^{\mathrm{b}}$ \\
Dried fruits $(n=10)$ & $2.91 \pm 0.11$ \\
Fermented samples $(n=14)$ & $9.21 \pm 0.58$
\end{tabular}

${ }^{\mathrm{a}}$ Grown on MRS agar with $0.1 \%$ natamycin, incubated anaerobically, Grampositive and catalase-negative, ${ }^{b}$ Values are means \pm standard deviation of $n$ determinants (two harvests) and each determinant was calculated as the average of duplicate counts.
LAB populations found on ripe and dried fruits were approximately 2.99 and $2.91 \log$ CFU g ${ }^{-1}$ (Table 5). Just like the yeasts, the LAB multiply during fermentation and therefore larger numbers of LAB were found in fermented fruit pulp compared with the unprocessed fruits (Table 5).

We characterized only a number of representative and predominant $\mathrm{LAB}$, collected from fruits harvested in two consecutive seasons; of each fruit type 10 samples were analysed in duplicate. LAB isolates from both years showed similar phenotypic properties.

The LAB found in ripe fruits were preliminary identified as Lactobacillus agilis (2 strains), L. minor (2 strains), L. confusus (1 strain) and L. fructosus (1 strain). In dried fruits L. minor (1 strain), L. divergens (2 strains) and 2 unidentified strains were found. The fermented fruit pulp harboured mostly L. agilis ( 9 strains) and L. plantarum (6 strains). The other species found in fermented fruit pulp included $L$. bifermentans (2 strains), $L$. divergens (2 strains), L. fermentum (1 strain), L. hilgardii (1 strain), L. minor (1 strain), Streptococcus spp. (2 strains) and 1 unidentified strain. The LAB results are preliminary being based on phenotypic properties, and need to be confirmed by molecular identification methods.

L. plantarum has been reported to be involved in many cereal-based African fermented foods such as $O g i, U_{j i}$ and Mahewu (Halm et al., 1993; Sanni, 1993; Holzapfel, 1997; Oyewole, 1997) as well as other fermented foods (Hammes and Tichaczek, 1994; Caplice and Fitzgerald, 1999; Leisner et al., 1999). Certain strains of Lactobacillus plantarum and L. agilis have been reported to have probiotic effects (Lee and Salminen, 1995).

\section{Conclusion}

This study showed that there is a transition from the predominance of non-fermentative yeasts to fermentative yeasts species as the masau fruit matures until it is fermented. $A$. pullulans, a non-fermentative yeast-like fungus was dominant on the unripe fruit surface. The ripe and dried fruits carried a mixture of non-fermentative and fermentative yeasts. The fermentative yeasts $S$. cerevisiae, I. orientalis and P. fabianii were dominant in the fermented masau fruit pulp. These yeasts should be tested for their functionality during the fermentation, and some might be useful as starter culture to produce better quality fermented masau fruit products. The yeasts were found co-existing with LAB in the ripe fruits and the fermented fruit pulp; likewise, the functionality of LAB in the fermentation should be investigated, in view to develop mixed yeast-LAB starter cultures to produce a fermented fruit product of stable and consistent quality.

\section{Acknowledgements}

The authors are grateful to the MacGillavry fund of The Royal Netherlands Academy of Arts and Sciences (KNAW) and the International Foundation for Science (IFS Grant No C/3737) for financial support. We are also grateful to $\mathrm{Mr}$ Mutseka, $\mathrm{Mr}$ Nyanga and Mr Mutemeri for their assistance during the collection of samples. 


\section{References}

Beech, F.W., 1993. Yeasts in cider-making, In: Rose, A.H., Harrisson, J.S. (Eds.), 2nd ed. The Yeasts, vol. 5. Academic Press, London, UK, pp. 169-214.

Brett, T.R.L., Nyamupingidza, E.N., Gurira, R.C., 1992. The analysis, identification and determination of toxic substances in Kachasu. Transactions of the Zimbabwe Science Association 66, 25-29.

Caplice, E., Fitzgerald, G.F., 1999. Food fermentations: role of microorganisms in food production and preservation. International Journal of Food Microbiology 50, 131-149.

Chand-Goyal, T., Spotts, R.A., 1996. Enumeration of bacterial and yeast colonists of apple fruits and identification of epiphytic yeasts on pear fruits in the Pacific Northwest United States. Microbial Research 151, 427-432.

Chivero, E.T., Mutukumira, A.N., Zvauya, R., 2001. Partial purification and characterisation of a xylanase enzyme produced by a micro-organism isolated from selected indigenous fruits of Zimbabwe. Food Chemistry 72, 179-185.

Clark, D.S., Wallace, R.H., David, T.J., 1954. Yeasts occurring on apples and in apple cider. Canadian Journal of Microbiology 1, 145-149.

Deak, T., 1993. Simplified techniques for identifying foodborne yeasts. International Journal of Food Microbiology 19, 15-26.

Deak, T., 2003. Detection, enumeration and isolation of yeasts. In: Robert, V. (Ed.), Yeasts in Food: Beneficial and Detrimental Effects. Behr's Verlag GmbH and Co, Hamburg, pp. 39-59.

Dennis, C., Davis, R.P., 1977. Susceptibility of strawberry varieties to postharvest fungal spoilage. Journal of Applied Bacteriology 42, 197-206.

Deshpande, M.S., Rule, V.B., Lynch, J.M., 1992. Aureobasidium pullulans in applied microbiology. A status report. Enzyme and Microbial Technology $14,514-527$.

Fleet, G.H., 1999. Microorganisms in food ecosystems. International Journal of Food Microbiology 50, 101-117.

Fleet, G.H., 2003. Yeasts in fruit and fruit products. In: Robert, V. (Ed.), Yeasts in Food: Beneficial and Detrimental Aspects. B. Behr's Verlag GmbH and Co, Hamburg, pp. 267-287.

Gadaga, T.H. (2000) Sensory properties of traditional fermented milk and milk fermented with three strains of Lactococcus lactis subsp. lactis and Candida kefyr isolated from Zimbabwean naturally fermented milk. Doctor Scientiarum thesis, Agricultural University of Norway, Ås, Norway.

Gadaga, T.H., Mutukumira, A.N., Narvhus, J.A., Feresu, S.B., 1999. A review of traditional fermented foods and beverages of Zimbabwe. International Journal of Food Microbiology 53, 1-11.

Gildemacher, P., Heijne, B., Silvestri, M., Houbraken, J., Hoekstra, E., Theelen, B., Boekhout, T., 2006. Interactions between yeasts, fungicides and apple fruit russeting. FEMS Yeast Research 6, 1149-1156.

Gobbetti, M., Corsetti, A., Rossi, J., 1994. The sourdough microflora interaction between lactic acid and yeasts: metabolism of amino acids. World Journal of Microbiology and Biotechnology 10, 275-279.

Gupta, A.K., Boekhout, T., Theelen, B., Summerbell, R., Batra, R., 2004. Identification and typing of Malassezia species by amplified fragment length polymorphism and sequence analyses of the Internal Transcribed Spacer and Large-Subunit Regions of Ribosomal DNA. Journal of Clinical Microbiology $42,4253-4260$.

Halm, M., Lillie, A., Sorensen, A.K., Jakobsen, M., 1993. Microbiological and aromatic characteristics of fermented maize doughs for kenkey production in Ghana. International Journal of Food Microbiology 19, $135-143$.
Hammes, W.P., Tichaczek, P.S., 1994. The potential of lactic acid bacteria for the production of safe and wholesome food. Lebensmittel Untersuchung und Forschung 198, 193-201.

Heard, G.M., Fleet, G.H., 1985. Growth of natural yeast flora during the fermentation of inoculated wines. Applied and Environmental Microbiology $50,727-728$.

Holzapfel, W.H., 1997. Use of starter cultures in fermentation on a household scale. Food Control 8, 241-258.

Jespersen, L., 2003. Occurrence and taxonomic characteristics of strains of Saccharomyces cerevisiae predominant in African indigenous fermented foods and beverages. FEMS Yeast Research 3, 191-200.

Kurtzman, C.P., Boekhout, T., Robert, V., Fell, W.J., Deak, T., 2003. Methods to identify yeasts. In: Robert, V. (Ed.), Yeasts in Food: Beneficial and Detrimental Aspects. B. Behr's Verlag GmbH and Co, Hamburg, pp. 69-117.

Lee, Y.-K., Salminen, S., 1995. The coming age of probiotics. Trends in Food Science and Technology 6, 241-244.

Leisner, J.J., Pot, B., Christensen, H., Rusul, G., Olsen, J.E., Wee, B.W., Muhammad, K., Ghazali, H.M., 1999. Identification of lactic acid bacteria from Chili Bo, a Malaysian food ingredient. Applied and Environmental Microbiology 65, 599-605.

Martini, A., Ciani, M., Scorzetti, G., 1996. Direct enumeration and isolation of wine yeasts from grape surfaces. American Journal of Enology and Viticulture $47,435-440$

Mbugua, S.K., 1985. Isolation and characterization of lactic acid bacteria during the traditional fermentation of uji. East African Agricultural and Forestry Journal 50, 36-43.

Nout, M.J.R., 2003. Traditional fermented products from Africa, Latin America and Asia. In: Robert, V. (Ed.), Yeasts in Food: Beneficial and Detrimental Effects. B. Behr's Verlag GmbH and Co, Hamburg, pp. 451-473.

O’Donnel, K.E., Cigelnik, N.S., Weber, N.S., 1997. Phylogenetic relationships among ascomycetous truffles and the true and false morels inferred from $18 \mathrm{~s}$ and 28s ribosomal DNA sequences analysis. Mycologia 89, 48-65.

Okagbue, R.N., Siwela, M., 2002. Yeasts and related microorganisms isolated from ripe marula fruits (Sclerocarya caffra). South African Journal of Science 98, 551-552.

Okagbue, R.N., Mwenje, E., Kudanga, T., Siwela, M., Sibanda, T., 2001. Isolation of Aureobasidium pullulans from Zimbabwean sources and glucosidase activities of selected isolates. South African Journal of Botany 67, 157-160.

Oyewole, O.B., 1997. Lactic fermented foods in Africa and their benefits. Food Control 8, 289-297.

Rosini, G., Federici, F., Martini, A., 1982. Yeast flora of grape berries during ripening. Microbial Ecology 8, 83-89.

Sanni, A.I., 1993. The need for process optimisation of African fermented foods and beverages. International Journal of Food Microbiology 18, 85-95.

Sanni, A.I., Lonner, C., Makinder, I., Johansson, M.-L., Molin, G., 1994. Starter cultures for the production of ogi, a fermented infant food from maize and sorghum. Chemie Mikrobiologie Technologie der Lebensmittel 16, 29-33.

Tredgold, M.H., 1986. Food Plants of Zimbabwe. Mambo Press, Gweru.

Van der Westhuizen, T.J., Augustyn, O.P.H., Khan, W., Pretorius, I.S., 2000. Seasonal variation of indigenous Saccharomyces cerevisiae strains isolated from vineyards in the coastal regions of the western ape in South Africa. South African Journal of Enology and Viticulture 21, 10-16.

Vos, P., Hogers, R., Bleeker, M., Reijans, M., van de Lee, T., Hornes, M., Frijters, A., Pot, J., Peleman, J., Kuiper, M., Zabeau, M., 1995. AFLP: a new technique for DNA fingerprinting. Nucleic Acids Research 23, 4407-4414.

Wijtzes, T., Bruggeman, M.R., Nout, M.J.R., Zwietering, M.H., 1997. A computerised system for the identification of lactic acid bacteria. International Journal of Food Microbiology 38, 65-70. 